\title{
A STEREOISOMER OF BENZYLPENICILLIN AS SUBSTRATE AND INDUCER FOR $\beta$-LACTAMASES
}

\author{
Tetsuo Sawai*, Tetsu Saito and Susumu Mitsuhashi \\ Department of Microbiology, School of Medicine, \\ Gunma University, Maebashi, Japan \\ * Present address : Faculty of Pharmaceutical Sciences, \\ Chiba University, Chiba, Japan
}

(Received for publication August 28, 1970)

The stereoisomer (trans-isomer) of benzylpenicillin was examined for its antibacterial activity and properties as a substrate and inducer of $\beta$-lactamases in comparison with benzylpenicillin. The minimum inhibitory concentrations of the trans-isomer against Staphylococcus aureus FDA 209P and Bacillus subtilis PCI 219 were 1.6 and $12.5 \mu \mathrm{g} / \mathrm{ml}$, respectively, which were about twenty-five times higher than those of benzylpenicillin. However, the transisomer was very stable to the penicillinases prepared from both $S$. aureus and Escherichia coli carrying an ampicillin-resistant $\mathrm{R}$ factor. The rates of hydrolysis of the trans-isomer by these pencillinases were less than $3 \%$ of the corresponding rates with benzylpenicillin as a substrate. The trans-isomer was a powerful inducer of the penicillinase synthesis by $S$. aureus and of the cephalosporinase synthesis by Proteus vulgaris.

$\beta$-Lactamases are enzymes that destroy both penicillins and cephalosporins by hydrolysis of the $\beta$-lactam ring. The enzymes are produced by a wide range of grampositive and gram-negative bacteria, and play an important role in bacterial resistance to penicillins and cephalosporins. Penicillin $\beta$-lactamases (penicillinases) are of ten inducible enzymes in gram-positive bacteria, but constitutive in gram-negative bacteria $^{13)}$. Cephalosporin $\beta$-lactamases (cephalosporinases), on the other hand, are mainly produced by gram-negative bacteria and may be inducible ${ }^{13}$. Both penicillins and cephalosporins act as inducers of the inducible $\beta$-lactamases. Their activity as inducers is influenced by the nature of the side-chain attached to the free amino group of the nuclei of penicillin and of cephalosporin ${ }^{52}$.

Fig. 1

In the present study, a stereoisomer (trans-isomer) of benzylpenicillin(Fig. 1), was examined as a substrate and inducer of certain $\beta$-lactamases, and its antibacterial activity determined. The $\beta$-lactamases were prepared and used for this purpose, i.e., penicillinase of Staphylococcus aureus (inducible enzyme), penicillinase of Escherichia coli carrying an ampicillinresistant $\mathrm{R}$ factor (constitutitive enzyme) and cephalosporinase of Proteus vulgaris (inducible enzyme).

Trans-isomer of benzylpenicillin

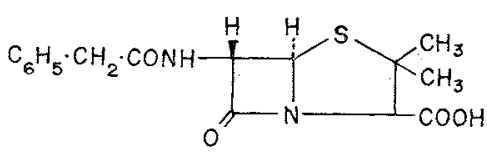

Benzylpenicillin (cis)

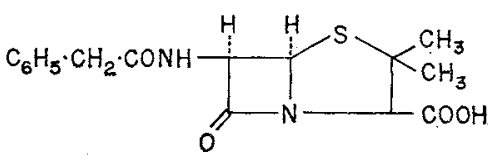




\section{Materials and Methods}

Bacterial Strain: Bacterial strains used were S. aureus FS108, S. aureus FDA 209P, Bacillus subtilis PCI 219, P. vulgaris GN76 and E. coli W 3630 carrying an ampicillinresistant $\mathrm{R}$ factor, $\mathrm{R}_{\mathrm{GN}_{14}}$. S. aureus $\mathrm{FDA} 209 \mathrm{P}$ and B. subtilis $\mathrm{PCI} 219$ are standard strains for the assay of antibacterial activity of drugs in this laboratory, and they are sensitive to benzylpenicillin and do not produce penicillinase. S. aureus FS108 and $P$. vulgaris GN $76^{13)}$ are clinically isolated strains and are high producer of penicillinase and cephalosporinase, respectively. The ampicillin-resistant $R$ factor, $R_{G_{N 14}}$, was obtained from a clinically isolated $E$. coil strain and successively transferred to $E$. coli W 3630 , a substrain of $\mathrm{K}_{\left.12^{6}\right)}$. E. coli $\mathrm{W} 3630$ carrying $\mathrm{R}_{\mathrm{GN}_{14}}$ produces constitutively the $\mathrm{R}$ factor-mediated penicillinase $^{6,13,14)}$.

Drugs: The trans-stereoisomer of benzylpenicillin was kindly provided by Toyo Jozo Co., Ltd., Tokyo and the compound used as the $\mathrm{N}, \mathrm{N}^{\prime}$-dibenzylethylendiamine salt. Benzylpenicillin was obtained from Meiji Seika Co., Ltd., Tokyo and cephaloridine from Torii Pharmaceutical Co., Ltd., Tokyo.

Media: Heart infusion broth (HI broth, Nihon Eiyo Kagaku Co., Ltd., Tokyo) was used for liquid culture of bacteria. For the determination of antibacterial activity of penicillins, heart infusion agar (HI agar, Nihon Eiyo Kagaku Co., Ltd., Tokyo) and peptone water ${ }^{6)}$ were used.

Assay of Antibacterial Activity: Antibacterial activities of penicillins were determined as follows: a loopful of an overnight culture in peptone water was spotted on HI agar plates containing serial two-fold dilutions of drug. The plates were incubated for 18 hours. at $37^{\circ} \mathrm{C}$. The degree of antibacterial activities of drug was expressed as the minimum inhibitory concentration of bacterial growth.

Induction of $\beta$-Lactamase: Induction of $\beta$-lactamase production was carried out according to the method described in the previous paper ${ }^{12}$. Five $\mathrm{ml}$ of an overnight culture in $\mathrm{HI}$ broth was diluted with $200 \mathrm{ml}$ of fresh $\mathrm{HI}$ broth and incubated with shaking at $37^{\circ} \mathrm{C}$. After 2 hours of incubation, samples of the culture $(20 \mathrm{ml})$ at exponential phase of growth were distributed in Erlenmeyer's flask, and varying amounts of the inducer were added to each flask. A sample without the inducer was used as control. After induction for 1.5 hours at $37^{\circ} \mathrm{C}$ with shaking, the production of the enzyme was terminated by addition of chloramphenicol to a concentration of $50 \mu \mathrm{g} / \mathrm{ml}$ and prompt chilling in an icewater bath.

Preparation of $\beta$-Lactamase Sample: Exo-penicillinase sample of $S$. aureus was prepared from the culture of $S$. aureus FS 108 in HI broth containing methicillin as an inducer for penicillinase ${ }^{12)}$. Penicillinase sample from $E$. coli $W 3630$ carrying $R_{G_{114}}$ was prepared by the method described previously ${ }^{13)}$.

Determination of $\beta$-Lactamase Activity and Measurement of the Amount of Penicillins Hydrolyzed: $\beta$-Lactamase activities were determined iodometrically according to the method of PERRET ${ }^{10)}$. The determination of penicillinase activities was carried out at $30^{\circ} \mathrm{C}$ in $0.1 \mathrm{M}$ phosphate buffer ( $\mathrm{pH} 5.8$ for staphylococcal penicillinase and $\mathrm{pH} 7.0$ for penicillinase of $\mathrm{R}$ factor) containing $8 \mathrm{~mm}$ benzylpenicillin as substrate, and one unit of the enzyme activity was defined as the activity that hydrolyzes $1 \mu$ mole of the substrate per hour under these conditions. The determination of cephalosporinase activity was carried out at $\mathrm{pH} 7.0$ in the same manner as the determination of penicillinase activity except that cephaloridine was used as a substrate, and that the amount of hydrolyzed cephaloridine was calculated on the basis of 1 mole hydrolyzed substrate being equivalent to 2 moles ( 4 atoms) of iodine ${ }^{1)}$. One unit of cephalosporinase activity was defined as the activity that hydrolyzes $1 \mu$ mole of the substrate per hour under the conditions mentioned above.

The assay of benzylpenicillin and its trans-isomer hydrolyzed by the penicillinases from $S$. aureus and $E$. coli carrying $\mathrm{R}_{\mathrm{GN}_{14}}$ was performed by the microiodometric method 
of Novick ${ }^{8,9)}$ using $0.1 \mathrm{M}$ phosphate buffer at $\mathrm{pH} 5.8$ (staphylococcal penicillinase) and at $\mathrm{pH} 7.0$ (penicillinase of $\mathrm{R}_{\mathrm{GN}_{14}}$ ). The penicillin was dissolved in the phosphate buffer at $2 \mathrm{~mm}$ of concentration. One $\mathrm{ml}$ of the penicillin solution was mixed with $1 \mathrm{ml}$ of penicillinase preparation in a centrifuge tube, and the mixture was incubated at $30^{\circ} \mathrm{C}$. After 1-hour incubation, the enzymatic reaction was stopped by chilling the mixture in an ice-bath, and simultaneously, $1.0 \mathrm{ml}$ of $0.15 \mathrm{M}$ sodium tungstate (in $2.0 \mathrm{M}$ acetate buffer, $\mathrm{pH}$ 4.0) was added to the mixture. The amount of the penicillin hydrolyzed was determined by the microiodometric method with the aid of the standard curves obtained by known amount of chemically hydrolyzed penicillins. Beforehand, it had been confirmed by use of the chemically hydrolyzed trans-isomer that the microiodometric assay method was applicable equally to the trans-isomer as well as to benzylpenicillin. It had been also confirmed experimentally that $\mathrm{N}, \mathrm{N}^{\prime}$-dibenzylethylendiamine does not inhibit the activities of the penicillinases used.

\section{Results}

\section{Antibacterial Activity of the Trans-Isomer}

The minimum inhibitory concentrations of the trans-isomer for $S$. aureus FDA $209 \mathrm{P}$ and B. subtilis PCI 219 on HI agar plate were $1.6 \mu \mathrm{g} / \mathrm{ml}$ and $12.5 \mu \mathrm{g} / \mathrm{ml}$, respectively. Under the same experimental conditions, the corresponding values for benzylpenicillin were 0.1 units $(0.065 \mu \mathrm{g}) / \mathrm{ml}$ and 0.8 units $(0.52 \mu \mathrm{g}) / \mathrm{ml}$, respectively. These results indicate that the stereochemical change in the nucleus of penicillin does not destroy the antibacterial activity of the drug, though it does cause a great decrease in the level of activity.

\section{Stability of the Trans-Isomer to Penicillinases from}

\section{S. aureus and $E$. coli Carrying $\mathrm{R}_{G \mathrm{~N} 14}$}

The rates of hyrolysis of the trans-isomer by the penicillinases from $S$. aureus FS108 and E. coli $\mathrm{R}_{\mathrm{GN}_{14}}$ could be measured at sufficiently high concentrations of the substrate. The results, together with those with benzylpenicillin, are shown in Table 1. The trans-isomer was very stable to both penicillinases when compared with benzylpenicillin. Such stability of the trans-isomer is comparable to those of semisynthetic penicillins such as methicillin and cloxacillin which are known as penicillinase-resistant penicillins.

\section{The Trans-Isomer as an Inducer for $\beta$-Lactamases}

Tables 2 and 3 show the amounts of the specific penicillinase and cephalosporinase activities formed by $S$. aureus FS108 and P. vulgaris GN76, respectively, during 1.5 hours of cultivation in the presence of varying concentrations of the trans-isomer and of benzylpenicillin. In S. aureus, the trans-isomer was a more
Table 1. Hydrolysis of benzylpenicillin and its trans-isomer by penicillinases from S. aureus FS 108 and $E$. coli $\mathrm{R}_{\mathrm{GN14}}$.

\begin{tabular}{c|c|c|c|c}
\hline Substrate & Source of & $\begin{array}{c}\text { Added } \\
\text { enzyme } \\
\text { activity } \\
\text { (units) }\end{array}$ & $\begin{array}{c}\text { Hydrolyzed } \\
\text { substrate } \\
\left(\times 10^{-3}\right. \\
\text { umoles })\end{array}$ & $\begin{array}{c}\text { Relative } \\
\text { rate of } \\
\text { hydrolysis/ } \\
\text { enzyme } \\
\text { activity } \\
(\%)\end{array}$ \\
\hline $\begin{array}{c}\text { Benzyl- } \\
\text { penicillin }\end{array}$ & $\begin{array}{l}\text { S. aureus } \\
\text { E. coli } \mathrm{R}_{\mathrm{GN} 14}\end{array}$ & 0.17 & 168 & 100 \\
\hline $\begin{array}{c}\text { Trans-isomer } \\
\text { of } \\
\text { benzyl- } \\
\text { penicillin }\end{array}$ & S. aureus & 17.0 & 368 & 100 \\
\hline
\end{tabular}


Table 2. Induction of penicillinase by benzylpenicillin and its trans-isomer in S. aureus FS108.

\begin{tabular}{c|c|c}
\hline Inducer & $\begin{array}{c}\text { Conc. of } \\
\text { inducer } \\
\text { (units or } \\
\mu \mathrm{g} / \mathrm{ml})\end{array}$ & $\begin{array}{c}\text { Specific penicillinase } \\
\text { activity } \\
\text { (units/mg dry } \\
\text { weight of bacteria) }\end{array}$ \\
\hline None & 0 & 11.2 \\
\hline Benzylpenicillin & $1(\mathrm{u} / \mathrm{ml})^{\mathrm{a})}$ & 15.7 \\
& 2 & 17.6 \\
\hline \multirow{2}{*}{ Trans-isomer } & $2(\mu \mathrm{g} / \mathrm{ml})$ & 41.4 \\
of & 5 & 22.8 \\
benzylpenicillin & 10 & 55.0 \\
\hline
\end{tabular}

a) The potency of benzylpenicillin used is 1,536 units $1,000 \mathrm{\mu g}$.
Table 3. Induction of cephalosporinase by benzylpenicillin and its transisomer in P. vulgaris GN76.

\begin{tabular}{c|c|c}
\hline Inducer & $\begin{array}{c}\text { Conc. of } \\
\text { inducer } \\
\left(\begin{array}{c}\text { units or } \\
\mu \mathrm{g} / \mathrm{ml})\end{array}\right.\end{array}$ & $\begin{array}{c}\text { Specific } \\
\text { cephalosporinase } \\
\text { activity } \\
\text { (units/mg dry } \\
\text { weight of bacteria) }\end{array}$ \\
\hline None & 0 & 17.0 \\
\hline Benzylpenicillin & $\begin{array}{c}20(\mathrm{u} / \mathrm{ml}) \\
100\end{array}$ & 75.4 \\
\hline Trans-isomer & $100(\mu \mathrm{g} / \mathrm{ml})$ & 257 \\
of & 500 & 67.6 \\
benzylpenicillin & 500 \\
\hline a) The potency of benzylpenicilin used is 1,536 \\
units $1,000 \% \mathrm{~g}$.
\end{tabular}

effective inducer than benzylpenicillin. Benzylpenicillin induced the formation of cephalosporinase in $P$. vulgaris at a lower concentration than did the trans-isomer, but the cephalosporinase activity in optimum concentrations of both inducers is about the same.

\section{Discussion}

During the past ten years, a number of semisynthetic penicillins have been introduced for clinical use. Some of them are very resistant to penicillinases, especially to staphylococcal penicillinase. These penicillins were obtained by means of modification of the sidechain attached to the free amino group of the penicillin nucleus, 6-aminopenicillanic acid. In the present work, it was shown that steric modification of the penicillin nucleus also resulted in high stability of the resulting drug to the penicillinases from both gram-positive and gram-negative bacteria. Though the antibacterial activity of the trans-isomer is lower than that of benzylpenicillin, the minimum inhibitory concentration of the trans-isomer against $S$. aureus, which was determined as $1.6 \mu \mathrm{g} / \mathrm{ml}$, does not exceed the practical levels for clinical use. It is expected, however, that modification of the side-chain of the transisomer will offer another route for the discovery of new semisynthetic penicillins.

It is well known that methicillin is the most active inducer and that benzylpenicillin, on the other hand, is a poor inducer of staphylococcal penicillinase ${ }^{5,12)}$. However, the trans-isomer of benzylpenicillin was very good inducer for staphylococcal penicillinase and its inducibility was found to be equivalent to that of methicillin. In contrast to the situation with staphylococcal penicillinase, benzylpenicillin is more active as an inducer of cephalosporinase in gram-negative bacteria than is methicillin ${ }^{2,3,7,11)}$. The trans-isomer showed about the same activity as an inducer of cephalosporinase in $P$. vulgaris as did benzylpenicillin. It has been suggested by several workers that a repressor, analogous to that of $\beta$-galactosidase, exists in the staphylococcal penicillinase synthesis system ${ }^{4}, 12$. However, the regulatory system of cephlosporinase synthesis in gram-negative bacteria has so far been unsolved. As shown in this paper, the trans-isomer is a powerful inducer of both penicillinase and cephalosporinase. Though this property is not a desirable one with respect to the use of this penicillin as a drug, the trans-isomer appears to be an interesting substance for the study on the regulatory systems of $\beta$-lactamase production.

\section{References}

1) Altcino, J. F. : Iodometric assay of natural and synthetic penicillins, 6-aminopenicillanic acid and cephalosporin C. Anal. Chem. $33: 648 \sim 649,1961$ 
2) Ayliffe, G. A. J. : Induction of cephalosporinase and penicillinase in Proteus species. Nature $201: 1032,1964$

3) Aymiffe, G. A. J. : Cephalosporinase and penicillinase activity of gram-negative bacteria. J. Gen. Microbiol. $40: 119 \sim 126,1965$

4) Cohen, S.; H. Sweeney \& F. Leitner : Temperature-sensitive repression of staphylococcal penicillinase. Science $149: 877 \sim 879,1965$

5) Crompton, B.; M. Jago, K. Crawford, G. G. F. Newton \& E. P. Abraham : Behavior of some derivatives of 7 -aminocephalosporanic acid and 6 -aminopenicillanic acid as substrates, inhibitors and inducers of penicillinases. Biochem. J. $83: 52 \sim 63,1962$

6) Egawa, R.; T. SaWaI \& S. Mutsuhashi : Drug resistance of enteric bacteria. XII. Unique substrate specificity of penicillinase produced by $\mathrm{R}$ factor. Jap. J. Microbiol. 11: 173 178, 1967

7) Hennessey, T. D. : Inducible $\beta$-lactamase in Enterobacteria. J. Gen. Microbiol. 49:277〜285, 1967

8) Novick, R. P. : Micro-iodometric assay for penicillinase. Biochem. J. $83: 236 \sim 240,1962$

9) Novick, R. P. : Analysis by transduction of mutations affecting penicillinase formation in Staphylococcus aureus. J. Gen. Microbiol. 33 : 121 136, 1963

10) Perret, C. J. : Iodometric assay of penicillinase. Nature $174: 1012 \sim 1013,1954$

11) SAвAтH, L. D.; M. JaGo \& E,P. Abrafam : Cephalosporinase and penicillinase activities of a $\beta$ lactamase from Pseudomonas pyocyanea. Biochem. J. $96: 739 \sim 752,1965$

12) Sawai, T.; H. Hashimoto, S. Mitsuhashi \& S. Yamagishr : Drug resistance of staphylococci. V. Two types of high-resistance to penicillin G in Staphylococcus aureus. Jap. J. Microbiol. $11: 179 \sim 188,1967$

13) Sawai, T.; S. Mitsuhasm \& S. Yamagishi : Drug resistance of enteric bacteria. XIV. Comparison of $\beta$-lactamases in gram-negative rod bacteria resistant to $\alpha$-aminobenzylpenicillin. Jap. J. Microbiol. $12: 423 \sim 434,1968$

14) Yamagishr, S.; K. O'mara, T. Sawai \& S. Mitsuhashi : The purification and properties of penicillin $\beta$-lactamases mediated by transmissible $\mathrm{R}$ factors in Escherichia coli. J. Biochem. 66 : $11 \sim 20,1969$ 